\title{
PENELITIAN KUALITAS AIR HUJAN UNTUK AIR MINUM DI KABUPATEN SORONG
}

\author{
M.Arief Rizka Kohilay \\ Program Studi Teknik Sipil Universitas Muhammadiyah Sorong \\ Jalan Pendidikan No. 27 Kota Sorong Provinsi Papua Barat \\ Email : arifkohilay@gmail.com
}

\begin{abstract}
ABSTRAK
Kabupaten sorong merupakan daerah dengan intensitas hujan yang cukup tinggi .Potensi air hujan yang cukup besar,tentunya dapat di manfaatkan sebagai sumber kehidupan dan kebutuhan sehari-hari, misalnya untuk minum dan kebutuhan lain.pemanfaatan air hujan sebagai air domestic dapat menanggulangi kekurangan air di musim kemarau, dan kebanjiran saat musim hujan.pengambilan data dan sample air hujan di ambil secara acak di wilayah Kabupaten Sorong, guna untuk mengetahui perhitungan water quality indeks untuk mengetahui kualitas dan potensi air hujan untuk air minum.
\end{abstract}

Kata kunci : Air hujan, Water quality indeks, Air minum

\section{PENDAHULUAN}

\section{Latar Belakang}

Indonesia merupakan Negara yang terletak di khatulistiwa atau bisa di sebut zamrud katulistiwa.Dengan letak geografisnya yang tepat berada di garis equator, dan memiliki hutan yang cukup luas, Indonesia merupakan salah satu Negara yang memiliki hutan hujan tropis teluas di dunia.secara hidrologis,Indonesia memiliki 2 musim yaitu musim kemarau dan musim hujan.Kabupaten sorong merupakan salah satu daerah di Indonesia dengan intensitas hujanyang cukup tinggi.potensi air hujan yang cukup besar, tentunya dapat dimanfaatkan sebagai sumber kehidupan dan kebutuhan sehari hari. 


\section{Tujuan Penelitian}

Mengetahui kualitas air hujan di kabupaten sorong dan menghitung kapasitas daya dukung air hujan dalam menyediakan air minum

\section{STATE OF THE ART}

Adapun penelitian terdahulu yang terkait dengan penelitian ini adalah sebagai berikut :

1. Samekto, C., \& Winata, E. S. (2010, June). Potensi sumber daya air di Indonesia. In Seminar Nasional ikasi Teknologi Penyediaan Air Bersih Kabupaten/Kota di Indonesia (pp. 1-20).

2. Alamsyah, S. (2006). Merakit Sendiri Alat Penjernihan Air Untuk Rumah Tangga. Kawan Pustaka.

3. Putra, M. H. S. (2014). PENELITIAN KUALITAS DAN POTENSI AIR HUJAN UNTUK AIR MINUM DI KOTA BANDAR LAMPUNG DENGAN METODE WATER QUALITY INDEKS (Doctoral dissertation, Universitas Lampung).

\section{METODE}

\section{Metode penelitian}

Tahap penelitian yang di gunakan adalah sebagai berikut

1.pengambilan data

2.pengolahan data

3.Analisi

Semua metode penulisan dan analisa dalam artikel ilmiah ini merujuk pada panduan penulisan tugas akhir Fakultas Teknik Universitas Muhammadiyah Sorong tahun 2014 (Pristianto, Amri, \& Rusdi, 2014).

\section{REFERENSI}


1. Samekto, C., \& Winata, E. S. (2010, June). Potensi sumber daya air di Indonesia. In Seminar Nasional ikasi Teknologi Penyediaan Air Bersih Kabupaten/Kota di Indonesia (pp. 1-20).

2. Alamsyah, S. (2006). Merakit Sendiri Alat Penjernihan Air Untuk Rumah Tangga. Kawan Pustaka.

3. Putra, M. H. S. (2014). PENELITIAN KUALITAS DAN POTENSI AIR HUJAN UNTUK AIR MINUM DI KOTA BANDAR LAMPUNG DENGAN METODE WATER QUALITY INDEKS (Doctoral dissertation, Universitas Lampung).

4. Departemen Kesehatan (Depkes). (2010), Peraturan Pemerintah Nomor 82 Tahun 2001Tanggal 14 Desember 2001 Tentang Pengalolaan Kualitas Air dan Pengendalian Pencemaran Air.

5. Harto, Sri Br. 1993. Analisis Hidrologi. Jakarta. PT. Gramedia Pustaka Utama. 